\title{
A Previdência Social: reforma ou há alternativas? *
}

\author{
Andressa Lopes Nulle ** \\ Cássio Silva Moreira ${ }^{* * *}$
}

\section{Resumo}

A situação da Previdência Social no Brasil tem sido amplamente questionada, principalmente, em razão da Proposta de Emenda Constitucional 287/2016 que tramita no Congresso Nacional. Considerando que a reforma criará barreiras ao acesso dos benefícios previdenciários, o objetivo principal deste estudo é descobrir se a reforma é indispensável para garantir a continuidade da Previdência Social ou se há alternativas sem que seja preciso fazer mudanças tão radicais. A fim de buscar esclarecimento sobre a existência ou não do déficit, identificaram-se os diferentes métodos de cálculo utilizados na aferição dos resultados financeiros da previdência e da seguridade. A partir das conclusões, demonstra-se que o sistema não é deficitário e que, inicialmente, existem outras providências a serem adotadas, já que, desde a promulgação da Constituição Federal de 1988, as reformas feitas não se mostraram suficientes para que os governantes deixem de utilizar o discurso da "insustentabilidade" desse sistema.

Palavras-chave: Solvência; Previdência Social; Brasil; Reforma; Alternativas.

\section{Abstract \\ Social Security: reform or are there alternatives?}

The situation of Social Security in Brazil has been widely questioned, mainly due to the proposal of the Constitutional Amendment 287/2016 that is processed in the National Congress. Given that the reform will create barriers to the access to social security benefits, the main objective of this study is to find out if the reform is indispensable to the continuity of Social Security or if there are alternatives without having to make such radical changes. In order to seek clarification on the existence or not of the deficit, we identified the different calculation methods used in the measurement of financial results of welfare and Social Security. Based on the conclusions, it is shown that the system is not deficient and that, initially, other measures should be adopted. The reason for this being that since the enactment of the Federal Constitution of 1988, the reforms have not proved enough to stop the government from using the discourse of the "unsustainability" of this system.

Keywords: Solvency; Social Security; Brazil; Reform; Alternatives.

JEL H1, H2, H3, H5 E H6.

\section{Introdução}

A Previdência Social brasileira é uma política integrante do Estado de Bem-Estar Social, definida como um direito social e está prevista nos artigos $6^{\circ}, 194,195,201$ e 202 da

\footnotetext{
*Artigo recebido em 31 de dezembro de 2017 e aprovado em 11 de setembro de 2019.

${ }^{* *}$ Administradora na Universidade Federal do Rio Grande do Sul (UFRGS), Porto Alegre, RS, Brasil. E-mail: and.nulle@gmail.com.

*** Professor do Instituto Federal do Rio Grande do Sul (IFRS), Porto Alegre, RS, Brasil. E-mail: cassio.moreira@poa.ifrs.edu.br. Site: www.cassiomoreira.com.br
} 
Constituição da República Federativa do Brasil de 1988. Foi o texto constitucional vigente que criou o amplo sistema de proteção social - Seguridade Social -, incluindo a Previdência como um componente dessa rede protetiva. Contudo, desde a promulgação da Constituição Federal de 1988, já ocorreram diversas alterações na Previdência Social, sendo as principais em 1998, 2002, 2003 e 2015. Alguns estudiosos assinalam que as mudanças ocorridas denotam um retrocesso em relação ao modelo de seguridade concebido originalmente. Já os governantes, para obterem a aprovação de tais propostas, apresentaram um histórico deficitário desse sistema como principal argumento.

Segundo a Associação Nacional dos Auditores Fiscais da Receita Federal do Brasil (Anfip) e o Departamento Intersindical de Estatística e Estudos Socioeconômicos (Dieese), recentemente, os debates acerca da reforma previdenciária ganharam força em função da desaceleração do crescimento econômico e do aumento da dívida pública federal (Anfip; Dieese, 2017). Conforme dados do Instituto Brasileiro de Geografia e Estatística (IBGE), o Produto Interno Bruto (PIB) de 2016 teve uma queda de 3,6\% em relação ao ano de 2015 e o PIB de 2015 também recuou 3,8\% comparado ao ano de 2014 (IBGE, 2017). De acordo com o Tesouro Nacional, a Dívida Pública Federal encerrou o ano de 2016 com um aumento de $11,45 \%$ em referência ao ano anterior (Brasil, 2017c). Além do discurso sobre o déficit previdenciário, os representantes do poder público estabelecem uma conexão entre esses dados econômicos e as pesquisas sobre o aumento da expectativa de sobrevida dos brasileiros, para fundamentar que os gastos públicos devem ser controlados e que é preciso fazer algumas reformas, incluindo a do sistema previdenciário brasileiro.

Há duas perspectivas em que se deseja aprofundar e comparar a fim de compreender o cenário político-econômico em torno do debate sobre a Proposta de Emenda Constitucional n. 287/2016. A primeira, que vem sendo adotada pelo Governo Temer, é marcada por políticas de austeridade em que se defende que embora a reforma previdenciária seja impopular, é necessária para ajustar as contas públicas, em razão do déficit nas contas da Previdência e porque no Governo Dilma houve um excesso de gastos, incluindo os sociais, que levaram ao agravamento da crise econômica.

Do ponto de vista contrário, não há falta de recursos na Previdência e os argumentos utilizados pelo governo são insubsistentes e não transmitem a realidade. Segundo Anfip e Dieese (2017), o governo utiliza um sistema atuarial que apresenta inconsistências nas projeções de curto prazo, de modo que seria muito improvável admitir que as estimativas para os próximos quarenta anos venham a se concretizar. Para os opositores, é preciso esclarecer os parâmetros que embasam o discurso do atual governo, já que seus representantes estão utilizando argumentos que, há décadas, são defendidos por quem acredita que o déficit fiscal resulta de gastos com os benefícios previdenciários e que a única alternativa para fazer o ajuste é retroceder em termos de direitos sociais.

Diante do exposto, o objetivo geral deste trabalho pode ser expresso com a seguinte pergunta: A Reforma Previdenciária, proposta pela PEC 287/2016, é indispensável para garantir a continuidade da Previdência Social no Brasil e ajustar as contas públicas? 
Como o governo está prestes a criar mais barreiras ao acesso desse sistema, pretendese encontrar uma coerência entre as informações que são divulgadas pelo Poder Público e pelos que se opõem à reforma, uma vez que a PEC 287/2016 é considerada a mais radical desde as mudanças já concretizadas. Desta forma, esta pesquisa visa a compreender se a reforma é primordial ou se há caminhos diferentes para garantir a perpetuidade do sistema previdenciário brasileiro.

O pressuposto adotado nesta pesquisa está em conformidade com a visão de que existem meios de garantir que o sistema previdenciário não entre em colapso, sem ter a necessidade de se fazer uma reforma tão ampla e restritiva. A fim de encontrar a resposta para o problema desta pesquisa, utilizaram-se os métodos de pesquisa bibliográfica e documental, pois, de acordo com Severino (2017), a pesquisa bibliográfica faz o uso dos registros existentes, isto é, o pesquisador realiza seu trabalho a partir das contribuições dos estudos anteriores. Em relação à pesquisa documental, o autor descreve que os documentos investigados ainda não tiveram tratamento analítico, ou seja, é a partir desses documentos que o pesquisador desenvolve sua investigação e análise. Sendo assim, foi feita uma busca tanto em dados oficiais publicados por órgãos governamentais e legislação previdenciária brasileira, quanto em artigos, livros, teses, relatórios técnicos, entre outras fontes, que possibilitaram explorar e confrontar as divergências deste tema.

O artigo está dividido em cinco seções. Além desta introdução, a primeira contextualiza a Previdência Social dentro do sistema da Seguridade Social; a segunda, em razão das diferentes visões sobre a solvência desse sistema, exibe o histórico de arrecadações e de despesas (período de 2011 a 2016) a partir das diferentes metodologias de cálculo usadas na aferição do resultado financeiro da Seguridade Social e da Previdência Social; a terceira analisa as mudanças citadas na PEC 287/2016, comparando os argumentos favoráveis e contrários à reforma previdenciária brasileira, além de verificar a existência de alternativas; por último, são apresentadas as conclusões.

\section{A Previdência Social no contexto da seguridade social}

A expressão Previdência surgiu na Constituição Federal de 1934 (art. 121, § 1º, alínea h) que estabeleceu a instituição da previdência por meio de contribuição igual da União, do empregador e do empregado, caracterizando a forma tripartite de custeio. No texto constitucional de 1946 utilizou-se a expressão Previdência Social, mas somente a Constituição Federal de 1988 que destinou um capítulo inteiro para tratar da Seguridade Social - um sistema que engloba os subsistemas: Previdência Social, Assistência Social e Saúde (Goes, 2015).

Segundo Boschetti (2004 apud Silva, 2011), a Seguridade Social instituída pela Constituição Federal de 1988 tornou-se um sistema híbrido, que mistura direitos oriundos do trabalho (Previdência Social), direitos de caráter universal (Saúde) e direitos seletivos (Assistência Social). Silva (2011) afirma que essa característica híbrida é explicitada nas 
diretrizes que o texto constitucional estabeleceu para a organização deste sistema, sendo estas um reflexo das forças existentes durante o processo constituinte, uma vez que os movimentos sociais e a expansão dos direitos sociais marcaram esse período pós-ditatorial.

No artigo 194 da Constituição Federal de 1988 consta que "a seguridade social compreende um conjunto integrado de ações de iniciativa dos Poderes Públicos e da sociedade, destinadas a assegurar os direitos relativos à saúde, à previdência e à assistência social" (Brasil, 2016, p. 117). No parágrafo único deste artigo são elencados alguns princípios (diretrizes) que devem nortear a atuação do poder público quanto à organização da Seguridade Social. São eles: universalidade da cobertura e do atendimento; uniformidade e equivalência dos benefícios e serviços entre as populações urbanas e rurais; seletividade e distributividade na prestação dos benefícios e serviços; irredutibilidade do valor dos benefícios; equidade na forma de participação no custeio; diversidade da base de financiamento; caráter democrático e descentralizado da administração mediante gestão quadripartite, com participação dos trabalhadores, dos empregadores, dos aposentados e do Governo nos órgãos colegiados (Brasil, 2016).

Ressalta-se que os princípios possuem interpretações específicas para cada um dos subsistemas da Seguridade Social. Por exemplo, o primeiro princípio, universalidade da cobertura e do atendimento, no caso da saúde, é amplamente aplicado, pois não há nenhuma restrição para os usuários. Em relação à assistência social, somente as pessoas que realmente necessitam têm acesso a esse serviço. No sistema previdenciário, apenas aqueles que contribuem financeiramente (Goes, 2015).

O Dieese (2007a) diz que ao integrar as ações da Previdência, da Assistência Social e da Saúde, considerando o princípio da universalidade da cobertura e do atendimento, a Constituição Federal de 1988 estabeleceu uma proteção social contra contingências sociais que podem comprometer a sobrevivência humana. Segundo o Dieese (2007a, p. 3) "a Seguridade Social brasileira, conforme concebida, é, portanto, promotora de uma distribuição menos desigual de renda e de acesso a bens".

Silva (2011) diz que o significado de Seguridade Social expresso na Constituição Federal vigente orienta o poder público a organizar esse sistema protetivo de forma coerente e articulada, porém faz uma ressalva quanto ao que realmente foi adotado no Brasil:

[...] O objetivo é assegurar direitos relativos à saúde, previdência e assistência social, com base em princípios que promovam a cidadania e um padrão de vida considerado satisfatório. Um sistema com fontes de financiamento de base diversificada, que realize seus gastos obedecendo aos fins que lhe são próprios, respaldado em um orçamento único, elaborado pelos órgãos que o compõem. Um sistema gerido democraticamente, que alcance universalmente a população brasileira. Mas, essa orientação constitucional não foi seguida pelo poder público. Não existe, no Brasil, um sistema coeso e consistente de seguridade social instalado (Silva, 2011 p. 101). 
De acordo com Mota (1995 apud Silva, 2011), embora os princípios que asseguram a universalização da seguridade social estejam descritos no texto constitucional, quando há agravamento de uma crise econômica, existe a tendência, por parte do poder público e dos que detêm grande parte do capital, em contestar esses direitos adquiridos, sob o pretexto da necessidade de adequá-los, por meio de reformas, à atual situação econômica do país.

Nesse contexto, Silva (2011) relata que o significado atribuído à Seguridade Social pelo texto constitucional está sendo desmantelado. A autora cita como exemplos dessa desconstrução:

[...] os frequentes abandonos dos princípios gerais da seguridade social; resistência de implementação do financiamento, considerando o princípio da equidade na participação do custeio, em favor da chamada austeridade fiscal, para atender aos objetivos de política econômica comprometida com o capital financeiro e não com a cidadania; a organização de cada uma dessas políticas em sistemas separados, sem articulação entre si, com gestão própria; as frequentes mudanças no texto constitucional, impondo regressividade aos direitos relativos à previdência social, tornando-a cada vez mais parecida com os seguros privados, a exemplo das alterações regressivas de 1998, $2002 \mathrm{e}$ 2003; a crescente privatização da saúde; a dispersão orçamentária e financeira, mediante a criação de Fundos específicos para a gestão de recursos de modo separado, ou seja, o Fundo Nacional da Saúde - FNS (recursos da saúde), Fundo Nacional de Assistência Social - FNAS (recursos da assistência social) e Fundo do Regime Geral de Previdência Social - FRGPS (recursos da previdência social) (Silva, 2011 p. 102).

Embora o verdadeiro sentido dessa rede protetiva esteja sendo desconstruído, não se pode negar a importância da sua existência. O Dieese (2007a) destaca que, na falta dessa proteção social, o acesso à saúde estaria condicionado ao poder aquisitivo individual ou familiar, além de que não existiriam recursos para distribuir na área da assistência social e que a previdência social pública poderia ser enquadrada como um contrato de seguro individual, ou seja, o valor do benefício estaria diretamente relacionado ao montante das contribuições realizadas pelo próprio indivíduo e, portanto, essa situação poderia gerar um aumento da desigualdade social no Brasil.

Diante deste contexto, o sistema previdenciário é um instrumento fundamental de proteção aos trabalhadores, uma vez que estabelece algumas garantias, prevalecendo, conforme Lúcio (2007), um contrato social que se materializa em compromissos entre as gerações para possibilitar o acesso ao bem-estar após a vida laboral.

Dentre os subsistemas da Seguridade Social brasileira, a Previdência é o único que é organizado sob a forma de regime geral, de caráter contributivo e de filiação obrigatória, conforme art. 201 da Constituição Federal de 1988. Apoiada no princípio da solidariedade entre as gerações, a Previdência é considerada como um regime de repartição simples, ou seja, é por meio das contribuições da atual classe trabalhadora que são pagos os benefícios dos que estão incapacitados, dos aposentados e dos pensionistas. Consequentemente, quando 
os segurados ativos chegarem à inatividade, outros trabalhadores estarão contribuindo para que os benefícios sejam pagos. Esse regime difere do modelo de capitalização, que tem como característica a individualidade, no qual o segurado contribui para o seu próprio futuro.

O art. 201 da Constituição Federal em vigor descreve os objetivos dos benefícios concedidos na área previdenciária - garantir a renda dos trabalhadores em eventos de doença, invalidez, morte e idade avançada; proteção à maternidade, especialmente à gestante; proteção ao trabalhador em situação de desemprego involuntário; salário-família e auxílioreclusão para os dependentes de baixa renda; pensão por morte do segurado, homem ou mulher, ao cônjuge ou companheiro e dependentes (Brasil, 2016).

Depois de expor a importância que a Previdência tem no contexto da Seguridade Social, na próxima seção serão apresentadas as fontes que financiam este subsistema, bem como as metodologias de cálculo que mostram os distintos resultados.

\section{A situação financeira da Previdência Social Brasileira}

Para compreender a situação financeira da Previdência Social brasileira, é importante identificar quais são as fontes de recursos que a financiam. Conforme o Dieese (2007a), a Seguridade Social não poderia ser mantida apenas com as contribuições incidentes sobre as folhas de pagamentos e sobre os rendimentos dos trabalhadores. Por isso, considerando o princípio da diversidade da base de financiamento, o texto constitucional vigente prevê, no artigo 195, que:

A seguridade social será financiada por toda a sociedade, de forma direta e indireta, nos termos da lei, mediante recursos provenientes dos orçamentos da União, dos Estados, do Distrito Federal e dos Municípios, e das seguintes contribuições sociais:

I - do empregador, da empresa e da entidade a ela equiparada na forma da lei, incidentes sobre:

a) a folha de salários e demais rendimentos do trabalho pagos ou creditados, a qualquer título, à pessoa física que lhe preste serviço, mesmo sem vínculo empregatício;

b) a receita ou faturamento;

c) o lucro;

II - do trabalhador e dos demais segurados da previdência social, não incidindo contribuição sobre aposentadoria e pensão concedidas pelo regime geral de previdência social de que trata o art. 201;

III - sobre a receita de concursos de prognósticos;

IV - do importador de bens ou serviços do exterior, ou de quem a lei a ele equiparar (BRASIL, 2016 p. 117-118).

Neste artigo, a Constituição Federal de 1988 estabelece que o governo também destine recursos para a Seguridade Social nas suas três esferas (União, Estados e Municípios). Esses recursos devem constar na Lei Orçamentária Anual (LOA), segundo o inciso III do parágrafo $5^{\circ}$ do art. 165 do texto constitucional. A LOA é composta por três orçamentos: fiscal; de investimento; da seguridade social (Brasil, 2016). 
É possível perceber que o texto constitucional indica um rol amplo e diversificado de possíveis fontes de financiamento e também determina que o poder público elabore um orçamento específico para a Seguridade Social, a fim de facilitar o controle da situação financeira desse sistema. Entretanto, alguns estudiosos acreditam que o orçamento da seguridade é agregado ao fiscal para dificultar a sua análise.

O Dieese (2007) afirma que:

Na questão orçamentária, a não publicação do Orçamento da Seguridade abre a possibilidade para afirmações e análises sobre o "déficit da previdência". Além disso, permite que receitas próprias da Seguridade sejam desviadas para outros fins e, ainda mais, que recursos sejam nela realocados como transferências do Tesouro e não como receitas próprias da Seguridade, reforçando o discurso do "déficit da previdência". E esse processo é facilitado pelo grande controle do Ministério da Fazenda sobre a arrecadação para o financiamento da Seguridade (Dieese, 2007a, p. 5).

As constatações de Gentil (2006) complementam esta afirmação do Dieese:

Se houvesse a elaboração, de forma isolada, do orçamento da seguridade social, ficaria revelado, com clareza: 1) que o desequilíbrio orçamentário está no orçamento fiscal e não no orçamento da seguridade social ou no orçamento da previdência social; 2) que a seguridade social não recebe recursos do orçamento fiscal, ao contrário, parte substancialmente elevada de seus recursos financia o orçamento fiscal; e, 3) que não é a previdência que causa problemas de instabilidade econômica e crise de confiança nos investidores, mas é a política econômica que atinge a previdência, a saúde pública e a assistência social, precarizando serviços essenciais à sobrevivência da classe trabalhadora (Gentil, 2006 p. 52-53).

O Dieese (2007b) explica que há três concepções de análise a respeito dos resultados financeiros da Previdência Social (a fiscalista, a pragmática e a constitucionalista). Por conta disso, há contradições acerca das contas da Previdência. Nas próximas subseções, serão apresentadas essas três metodologias de cálculo, já que cada visão vai considerar uma base de financiamento distinta e, deste modo, os resultados também serão divergentes. Para o Dieese (2007b) essas perspectivas são reflexos, na verdade, das discordâncias existentes acerca da função do Estado.

\subsection{A situação financeira da Previdência sob a ótica fiscalista}

A visão fiscalista não considera todas as fontes de financiamento descritas no texto constitucional, uma vez que utiliza como base a Lei de Responsabilidade Fiscal (LRF) - Lei Complementar 101/2000. A principal característica desta perspectiva é analisar a Previdência Social isoladamente, ou seja, não considera a Seguridade Social como um sistema integrado entre a Saúde, a Assistência e a Previdência Social. A Tabela 1 demonstra o resultado financeiro da Previdência no período de 2011 a 2016, conforme a visão fiscalista, que é a perspectiva adotada pelo governo. 
Tabela 1

Visão fiscalista

\begin{tabular}{l|c|c|c|c|c|c}
\hline \multicolumn{6}{c}{ Resultado Financeiro da Previdência Social de 2011 a 2016 - Em R\$ Bilhões } \\
\hline Anos & 2011 & 2012 & 2013 & 2014 & 2015 & 2016 \\
\hline $\begin{array}{l}\text { Arrecadação } \\
\text { Líquida }\end{array}$ & 245,9 & 275,8 & 307,1 & 337,5 & 350,3 & 358,1 \\
\hline $\begin{array}{l}\text { Benefícios } \\
\text { Previdenciários }\end{array}$ & $(281,4)$ & $(316,6)$ & $(357,0)$ & $(394,2)$ & $(436,1)$ & $(507,9)$ \\
\hline $\begin{array}{l}\text { Resultado } \\
\text { Previdenciário }\end{array}$ & $(35,5)$ & $(40,8)$ & $(49,9)$ & $(56,7)$ & $(85,8)$ & $(149,7)$ \\
\hline
\end{tabular}

Fontes: Secretaria da Previdência (Brasil, 2017e). Elaboração dos autores.

Ressalta-se que o Fundo do Regime Geral da Previdência Social (FRGPS) foi instituído através da LRF com o objetivo de prover recursos para o pagamento dos benefícios previdenciários. Contudo, o artigo 68 desta lei fere o princípio da diversidade da base de financiamento da Seguridade Social ao considerar como fonte de financiamento para a Previdência apenas as receitas das contribuições sociais, previstas na alínea $a$ do inciso I (contribuição social do empregador, da empresa e da entidade a ela equiparada incidente sobre a folha de salários e demais rendimentos do trabalho pagos à pessoa física) e no inciso II (contribuição social do trabalhador e dos demais segurados da previdência social) do art. 195 da Constituição Federal de 1988.

Gentil (2006) reforça a inconstitucionalidade deste artigo da LRF ao mencionar que a criação de um fundo exclusivo para a Previdência ignora o conceito integrado de Seguridade Social expresso no texto constitucional. Além disso, destaca que os recursos da Contribuição para o Financiamento da Seguridade Social (Cofins) e da Contribuição Social sobre o Lucro Líquido (CSLL) são tidos como alheios ao orçamento previdenciário e, sendo assim, podem ser enquadrados como transferências da União, enquanto deveriam ser registrados como recursos próprios e não recursos transferidos. De acordo com a autora, o governo utiliza esta nomenclatura (recursos transferidos da União) para saldar o suposto déficit previdenciário e, por isso, possibilita que seja feita uma análise equivocada sobre a situação financeira da Previdência Social, colocando-a como o principal item na pauta de reformas em razão de prejudicar o equilíbrio fiscal do governo.

Ao analisar, de forma mais detalhada, as demonstrações contábeis do FRGPS, percebe-se que as maiores fontes de receitas são as contribuições patronais, as contribuições dos segurados e os juros e encargos de mora sobre créditos tributários.

Tabela 2

Descrição das maiores receitas do FRGPS

\begin{tabular}{l|c|c}
\hline Receitas do FRGPS & 2015 & 2016 \\
\hline Contribuições Patronais & $202.717 .278 .344,92$ & $254.485 .648 .771,17$ \\
\hline Contribuições dos Segurados & $114.068 .663 .062,22$ & $77.186 .852 .211,71$ \\
\hline Juros e Encargos de Mora sobre Crédito Tributário & $5.267 .592 .979,49$ & $4.996 .615 .622,35$ \\
\hline Total (R\$) & $322.053 .534 .386,63$ & $336.669 .116 .605,23$ \\
\hline
\end{tabular}

Fontes: Instituto Nacional do Seguro Social - INSS (INSS, 2016). Elaboração própria. 
De acordo com a Tabela 2, fica evidente que, praticamente, boa parte da receita considerada pelo governo para o financiamento da Previdência (Tabela 1) advém dos recursos dos empregadores e dos trabalhadores, ou seja, o Poder Executivo desconsidera no cálculo as alíneas b e c do inciso I e os incisos III e IV do artigo 195 da Constituição Federal de 1988.

De forma a ratificar o que foi exposto, o relatório final da Comissão Parlamentar de Inquérito do Senado Federal destinada a investigar a contabilidade da previdência social (CPIPrev), publicado em outubro de 2017, aponta que tanto o Governo Federal, quanto o Tribunal de Contas da União (TCU) apresentam resultados parecidos quanto ao crescente déficit da Seguridade Social, atribuindo à Previdência a maior responsabilidade por esse crescimento. Contudo, a CPIPrev apresenta as divergências apontadas pela Anfip e por alguns especialistas em relação às contas do governo, evidenciando a omissão de várias receitas, além da inclusão de despesas que, constitucionalmente, não devem estar atreladas à seguridade (CPIPrev, 2017).

Na subseção posterior será apresenta a visão pragmática, a qual amplia um pouco a concepção de receita ao adicionar os valores tidos como renúncias previdenciárias.

\subsection{A situação financeira da Previdência sob a ótica pragmática}

Outra maneira de calcular o resultado financeiro da Previdência Social é fazer a soma das receitas das contribuições previdenciárias de trabalhadores e de empresas sobre a folha com o valor referente às renúncias de contribuições previdenciárias. Nesta perspectiva, também se avalia apenas a Previdência, sem considerar os demais subsistemas da Seguridade (Dieese, 2007b).

Ao analisar o relatório da execução orçamentária do Governo Federal, é possível identificar os itens que compõem as renúncias previdenciárias. Neste documento, o Tesouro Nacional apresenta a projeção da renúncia de receitas previdenciárias, desmembrando-a nas seguintes partes: Desoneração da folha, Simples Nacional, Entidades Filantrópicas, Exportação Rural, MEI (Microempreendedor Individual), Olimpíadas e Dona de Casa (Brasil, 2017d). A Tabela 3 apresenta a estimativa do governo para o montante de renúncias no ano de 2017, que é de aproximadamente R $\$ 62$ bilhões.

Tabela 3

Projeção de renúncias previdenciárias para 2017

\begin{tabular}{l|c|c|c|c|c|c}
\hline \multicolumn{7}{c}{ Renúncia de Receitas Previdenciária - Projeção 2017 - Em R\$ Milhões } \\
\hline $\begin{array}{l}\text { Desoneração da } \\
\text { Folha }\end{array}$ & $\begin{array}{c}\text { Simples } \\
\text { Nacional }\end{array}$ & Filantrópicas & $\begin{array}{c}\text { Exportação } \\
\text { Rural }\end{array}$ & MEI & Olímpiadas & $\begin{array}{c}\text { Dona de } \\
\text { Casa }\end{array}$ \\
\hline 17.030 & 24.930 & 12.541 & 6.260 & 1.556 & 24 & 241 \\
\hline
\end{tabular}

Total R\$ 62.582

Fontes: Tesouro Nacional (Brasil, 2017d). Elaboração própria. 
De acordo com os dados disponibilizados pela Secretaria da Previdência (2017), nos anos 2015 e 2016, foram contabilizados como renúncias previdenciárias mais de R\$ 40 bilhões por ano. A Tabela 4 demonstra o resultado financeiro da Previdência, na visão pragmática, desses dois anos. Logicamente, também apresenta um déficit, porém menor do que os valores apresentados sob a ótica fiscalista.

Tabela 4

Visão pragmática

\begin{tabular}{l|c|c}
\hline \multicolumn{3}{c}{ Resultado Financeiro da Previdência Social de 2015 e 2016 - Em R\$ Bilhões } \\
\hline Anos & 2015 & 2016 \\
\hline Arrecadação Líquida & 350,272 & 358,137 \\
\hline Renúncias Previdenciárias & 40,831 & 43,420 \\
\hline Benefícios Previdenciários & $(436,090)$ & $(507,871)$ \\
\hline Resultado Previdenciário & $(44,986)$ & $(106,313)$ \\
\hline
\end{tabular}

Fontes: Secretaria da Previdência (Brasil, 2017e). Elaboração própria.

Na concepção do Dieese (2007):

Quanto às renúncias fiscais, o entendimento é que a decisão de isentar determinados grupos da obrigatoriedade de recolher valores correspondentes às suas contribuições previdenciárias sobre rendimentos do trabalho deve implicar em ônus para o Tesouro Nacional e não para os demais contribuintes (Dieese, 2007b, p. 7).

Corroborando com este entendimento, descrito pelo Dieese, os defensores da visão constitucionalista usam não somente as renúncias previdenciárias em seus argumentos, como também apontam as demais fontes desconsideradas, tanto na visão fiscalista, quanto na pragmática.

\subsection{A situação financeira da Previdência sob a ótica constitucionalista}

A metodologia constitucionalista abrange, de certa maneira, todas as vertentes que questionam o cálculo do governo. Tal perspectiva adota o conceito de um sistema unificado de proteção social, uma vez que utiliza todas as fontes de financiamento arroladas no artigo 195 da Constituição Federal de 1988. Logo, "o modelo constitucional de financiamento da Seguridade Social baseia-se na pluralidade de fontes, com contribuições sociais incidentes sobre o faturamento, a folha de pagamentos, o lucro das empresas e os salários dos trabalhadores [...]" (Anfip, 2016, p. 45).

Tanto a Anfip, quanto o Dieese adotam esta visão. Conforme a Tabela 5, é possível verificar os resultados financeiros de todo o sistema.

Considerando os dados da Tabela 5, até 2015, a Seguridade Social apresentou resultados positivos, divergindo dos dados disponibilizados pelo poder público porque, de acordo com esta visão, este não vem cumprindo com a sua parte do financiamento tripartite da Seguridade. 
Tabela 5

Visão Constitucionalista

\begin{tabular}{l|c|c|c|c|c|c}
\hline \multicolumn{7}{c}{ Resultado financeiro da Seguridade Social de 2011 a 2016 - Em R \$ Bilhões } \\
\hline Anos & 2011 & 2012 & 2013 & 2014 & 2015 & 2016 \\
\hline Receitas & 527,226 & 595,298 & 651,475 & 688,375 & 694,497 & 718,985 \\
\hline Despesas & $(451,323)$ & $(512,953)$ & $(574,653)$ & $(632,092)$ & $(683,058)$ & $(775,983)$ \\
\hline Total & 75,902 & 82,845 & 76,822 & 56,283 & 11,439 & $(56,998)$ \\
\hline
\end{tabular}

Fonte: Anfip (2017). Elaboração própria.

A Anfip disponibilizou os resultados apurados para o ano de 2016 apenas no final de 2017, mencionando que a justificativa para esse déficit está atrelada aos reflexos da crise econômica, ou seja, fatores conjunturais que acabaram por afetar o histórico superavitário da seguridade (Anfip, 2017).

A fim de cumprir a determinação constitucional, conforme Anfip e Dieese (2017), o governo deve integrar as seguintes receitas: a CSLL, a Cofins e parte da contribuição para os Programas de Integração Social e de Formação do Patrimônio do Servidor Público (PISPasep). A Tabela 6 demonstra os valores arrecadados, nos últimos dois anos, dessas contribuições que foram excluídas do resultado financeiro da Previdência apresentado pelo governo.

Tabela 6

Fontes de financiamento não computadas pelo governo

\begin{tabular}{l|c|c}
\hline Arrecadações & 2015 & 2016 \\
\hline Cofins & 201,673 & 208,291 \\
\hline CSLL & 61,382 & 69,465 \\
\hline PIS/Pasep & 53,781 & 55,407 \\
\hline Total R\$ - Em Bilhões & 316,836 & 333,163 \\
\hline
\end{tabular}

Fonte: Secretaria da Receita Federal do Brasil (2015); Secretaria da Receita Federal do Brasil (2016). Elaboração própria.

Percebe-se que esses valores seriam mais que suficientes para cobrir os "déficits" da Previdência de R \$ 85,8 bilhões, em 2015, e de R \$ 149,7 bilhões em 2016. Além dos valores arrecadados com essas contribuições não contabilizadas, o déficit - declarado pelo governo poderia ter sido suprido em parte pela Desvinculação de Receitas da União (DRU), que totalizou, em 2015, R\$ 61 bilhões - recursos estes que deveriam constar como receitas da Seguridade.

Quanto à DRU, esta foi criada com o objetivo de desvincular a destinação da arrecadação de impostos e contribuições sociais da União, isto é, permite que o governo use livremente parte desses recursos para custear outras despesas (Anfip; Dieese, 2017). Em 2016, a Emenda Constitucional de n. 93, aprovou a prorrogação da DRU, aumentando o percentual de $20 \%$ para $30 \%$, e permitiu que a desvinculação de receitas também fosse aplicada para os Estados, Distrito Federal e Municípios. 
Para contra-argumentar, o governo disponibilizou dados referentes aos seus cálculos da Seguridade Social. Em 2016, as contas apresentaram um déficit de R \$ 258, 7 bilhões. Para o governo, a DRU não retira recursos da Seguridade, pois os recursos que são desvinculados acabam retornando para reduzir o "rombo" desse sistema. O valor desvinculado pela DRU, em 2016, foi de R $\$ 91,7$ bilhões, ou seja, de acordo com o poder público, mesmo que essas receitas não tivessem sido retiradas da Seguridade, o sistema continuaria deficitário (Brasil, 2017b).

Conforme a CPIPrev (2017), não existe justificativa para a perpetuação do mecanismo da DRU, uma vez que o próprio governo afirma que os recursos são integralmente repostos, mostrando-se incoerente as alegações do Poder Executivo.

A fim de expor as principais contradições existentes a respeito do resultado financeiro da Previdência e da Seguridade, o Quadro 1 traz um comparativo entre os principais argumentos utilizados pelo Governo e pelos opositores.

Quadro 1

Comparativo entre os argumentos do Governo e da oposição

\begin{tabular}{|c|c|c|}
\hline Tópicos divergentes & Governo & Opositores à Reforma \\
\hline $\begin{array}{l}\text { Déficit na Previdência } \\
\text { e na Seguridade }\end{array}$ & $\begin{array}{l}\text { O governo alega um déficit bilionário } \\
\text { e crescente. Para o Poder Público, a } \\
\text { ampla divulgação, por parte dos seus } \\
\text { críticos, dos cálculos até o ano de } \\
2015 \text { é proposital, pois com os dados } \\
\text { de } 2016 \text {, torna-se impossível mostrar } \\
\text { resultados positivos. }\end{array}$ & $\begin{array}{l}\text { Os dados apresentados são da Seguridade } \\
\text { Social, visto ser inconstitucional falar em } \\
\text { déficit previdenciário, uma vez que é um } \\
\text { subsistema da Seguridade e o histórico desse } \\
\text { sistema exibe saldo positivo. Ressaltam que } \\
\text { a Constituição Federal vigente estabelece } \\
\text { que seja feito um orçamento único, com } \\
\text { diversas fontes de financiamento } \\
\text { (dispositivo não respeitado nos cálculos } \\
\text { feitos pelo Poder Público). } \\
\text { De fato, constatou-se que apenas em outubro } \\
\text { de } 2017 \text {, a ANFIP divulgou os resultados da } \\
\text { Seguridade no ano de 2016, os quais foram } \\
\text { negativos. }\end{array}$ \\
\hline $\begin{array}{l}\text { RGPS (Regime Geral } \\
\text { de Previdência } \\
\text { Social) e RPPS } \\
\text { (Regimes Próprios de } \\
\text { Previdência Social) }\end{array}$ & $\begin{array}{l}\text { O governo insere, no orçamento da } \\
\text { seguridade, as receitas e despesas } \\
\text { relativas ao RPPS. No ano de } 2016 \text {, } \\
\text { lançou como receita R\$ } 33,6 \text { bilhões } \\
\text { de contribuições e como despesas R\$ } \\
110,8 \text { bilhões referentes aos } \\
\text { pagamentos dos benefícios desse } \\
\text { regime. } \\
\text { Para o governo, os opositores não } \\
\text { apenas retiram do cálculo as receitas } \\
\text { e despesas da previdência dos } \\
\text { servidores públicos civis e militares } \\
\text { federais, como também não indicam } \\
\text { qual a fonte de custeio a ser utilizada; }\end{array}$ & $\begin{array}{l}\text { Não consideram na sua metodologia de } \\
\text { cálculo, pois a Constituição Federal prevê } \\
\text { um capítulo distinto para tratar do RPPS, } \\
\text { portanto, para eles, não faz parte da } \\
\text { Seguridade Social. } \\
\text { Além disso, os regimes próprios possuem } \\
\text { fontes de custeio diferentes e específicas, } \\
\text { que, no caso de apresentarem saldo positivo, } \\
\text { não podem ser utilizadas para financiar } \\
\text { benefícios do RGPS ou qualquer benefício } \\
\text { da Seguridade Social. }\end{array}$ \\
\hline
\end{tabular}

Continua... 


\begin{tabular}{|c|c|c|}
\hline Tópicos divergentes & Governo & Opositores à Reforma \\
\hline $\begin{array}{l}\text { Renúncias } \\
\text { Previdenciárias }\end{array}$ & $\begin{array}{l}\text { Não faz o enquadramento das } \\
\text { renúncias previdenciárias como } \\
\text { receita. Justifica que, mais da metade } \\
\text { desse dinheiro, beneficia micro e } \\
\text { pequenas empresas, no âmbito do } \\
\text { Simples, representando } 57 \% \text { do total } \\
\text { das isenções, em } 2016 \text {. } \\
\text { Logo, as renúncias não estão } \\
\text { concentradas nas grandes empresas e, } \\
\text { se revogadas, poderão inviabilizar } \\
\text { muitas dessas empresas. }\end{array}$ & $\begin{array}{l}\text { Apontam a preocupante tendência de } \\
\text { redução do superávit, já que o resultado } \\
\text { financeiro da seguridade, em } 2015 \text {, caiu } \\
\text { significativamente em relação ao ano de } \\
2014 \text {. Conforme os críticos, isso é fruto } \\
\text { da recessão econômica e também da } \\
\text { política de renúncias tributárias. Inclusive, } \\
\text { mencionaram que essa situação iria se } \\
\text { repetir em 2016, apresentando pela primeira } \\
\text { vez, em mais de duas décadas, um resultado } \\
\text { negativo nas contas da Seguridade. } \\
\text { Quanto ao assunto das renúncias, os } \\
\text { opositores consideram os valores que } \\
\text { deveriam integrar as receitas da Seguridade } \\
\text { Social e não apenas da Previdência. Por essa } \\
\text { razão, declaram que, em } 2015 \text {, o valor } \\
\text { desonerado com Cofins, CSLL, PIS/Pasep e } \\
\text { com a isenção da contribuição patronal para } \\
\text { a Previdência alcançou R\$ } 157 \text { bilhões. }\end{array}$ \\
\hline $\begin{array}{l}\text { Desvinculações de } \\
\text { Receitas da União } \\
\text { (DRU's) }\end{array}$ & $\begin{array}{l}\text { O governo não considera, como } \\
\text { receita, o valor desvinculado pela } \\
\text { DRU, porque defende que atualmente } \\
\text { não retira dinheiro da Seguridade, ou } \\
\text { seja, não tem efeito, pois outros } \\
\text { recursos são injetados a esse } \\
\text { orçamento a fim de fazer uma } \\
\text { devolução. }\end{array}$ & $\begin{array}{l}\text { Para os críticos, o argumento do governo } \\
\text { não faz sentido, pois se os recursos da DRU } \\
\text { não retiram verbas da Seguridade, em } \\
\text { função dos aportes que são feitos para cobrir } \\
\text { "o déficit", por que ainda utilizam esse } \\
\text { instrumento? E qual o motivo da recente } \\
\text { elevação do percentual de } 20 \% \text { para } 30 \% \text { ? } \\
\text { De acordo com a oposição, a DRU aumenta, } \\
\text { na prática, o déficit da Seguridade Social e, } \\
\text { portanto, potencializa os discursos } \\
\text { favoráveis à reforma. }\end{array}$ \\
\hline
\end{tabular}

Fontes: Anfip e Dieese (2017); Ministério da Fazenda (Brasil, 2017b); Tesouro Nacional (Brasil, 2017d); Secretaria da Previdência (Brasil, 2017e).

Após elencar as principais divergências acerca da situação financeira da Seguridade e da Previdência, serão apontados, na seção subsequente, alguns pontos da PEC 287/2016.

\section{A Reforma Previdenciária}

Dividiu-se esta seção em três partes com o objetivo de facilitar a compreensão deste tema. Na primeira subseção será exposto o contexto político-econômico no qual a reforma previdenciária está inserida. Na segunda parte, serão apresentadas as novas regras que passarão a ser exigidas para a concessão dos benefícios, expondo os argumentos favoráveis e contrários à reforma. Por fim, serão identificadas as alternativas existentes para garantir a sobrevivência do sistema previdenciário brasileiro. 
Andressa Lopes Nulle, Cássio Silva Moreira

\subsection{O contexto mais amplo da reforma}

A fim de contextualizar a PEC 287/2016, ressalta-se que esta faz parte de um pacote de medidas econômicas do Governo Temer. Além da reforma previdenciária, estão incluídas a criação de um teto dos gastos público (Emenda Constitucional 95/2016), a reforma trabalhista (Lei 13.467/2017), a lei que regulamenta a terceirização (Lei 13.429/2017) e o aumento da desvinculação de receitas (Emenda Constitucional 93/2016).

A Emenda Constitucional 95/2016, que criou o "Novo Regime Fiscal", acabará limitando a atuação, nos 20 anos seguintes, dos próximos governantes em função da criação do teto para os gastos públicos, reduzindo a aplicação de recursos, em várias áreas, para direcioná-los ao pagamento da dívida pública.

A aprovação da reforma trabalhista (Lei 13.467/2017) e da lei que regulamenta a terceirização (Lei 13.429/2017) alteram as configurações das relações trabalhistas, mas, sobretudo, o que não se pode esquecer é que os recursos pagos pelo empregado e pelo empregador são as principais fontes de arrecadação da Previdência, ou seja, há uma linha muito próxima entre o Direito do Trabalho e o Direito Previdenciário.

Outra contradição é em relação à Emenda Constitucional 93/2016, uma vez que o governo declara um déficit crescente no sistema previdenciário, porém aprova o aumento do percentual que desvincula o uso da arrecadação de tributos, inclusive dos que deveriam ser destinados especificamente para o custeio da Previdência, da Assistência Social e da Saúde.

Vale ressaltar que o cenário político-econômico, o qual propiciou colocar em pauta essas reformas, vem se caracterizando pela austeridade desde 2014. Os argumentos que sustentam essa austeridade fiscal relacionam a melhora das contas públicas e o aumento da competitividade no setor privado com o corte dos gastos públicos e a redução de salários. Fórum 21 et al. (2016) relatam que a economia brasileira apresentou uma desaceleração, no período de 2011 a 2014, não apenas por causa da política fiscal adotada pelo governo, mas também pela redução do ciclo doméstico de consumo e de crédito, além dos reflexos da crise internacional. Neste período, a taxa de investimento parou de crescer e, confiando no setor privado, o governo aumentou consideravelmente os subsídios e desonerações com o objetivo de trazer incentivos aos investimentos privados. Esta estratégia de governo não trouxe os resultados esperados, tendo uma piora nos indicadores fiscais em função da queda do crescimento econômico e também por causa das desonerações.

Ainda na tentativa de reaquecer a economia, o Ministro da Fazenda, Joaquim Levy, na época, fez um ajuste fiscal na economia por meio de cortes nos gastos públicos e pela redução de salários, tendo como objetivos equilibrar a dívida pública e aumentar os lucros das empresas e consequentemente a competitividade do setor privado. Contudo, o resultado foi adverso, pois a situação econômica do país se agravou em razão do aumento da dívida 
pública e do déficit público, caracterizando a maior recessão das últimas décadas (Fórum 21 et al., 2016).

De acordo com Fórum 21 et al. (2016, p. 9), “[...] para determinados interesses políticos, o ajuste se mostrou funcional ao gerar desemprego, queda de salários reais e assim mudar a correlação de forças para favorecer a imposição de outro projeto de país [...]”. Diante do exposto, é possível perceber que turbulências, incertezas e disputas são algumas das palavras que podem descrever o panorama político-econômico do Brasil nos últimos anos. Em face do caos, principalmente político, que acaba trazendo consequências econômicas ao país, o conflito de interesses motiva as declarações feitas, ora pelos governantes, ora pelos opositores. Para os apoiadores dessas reformas, as medidas propostas serão capazes de, no longo prazo, reativar o crescimento econômico à medida que se vai resgatando a confiança do setor privado. Não obstante, para os opositores, os gastos sociais não são a causa do desajuste fiscal, assim como a Previdência Social não é a responsável pelas crises de confiança nos investidores.

Por essas razões se fez necessário apresentar, primeiramente, o contexto mais amplo em que essas medidas econômicas estão inseridas, em especial a da reforma previdenciária, que é objeto de estudo deste artigo. Na sequência, serão apresentadas as mudanças que estão sendo propostas na Previdência Social, bem como os argumentos favoráveis e contrários à reforma e, por último, as alternativas existentes a esta.

\subsection{As novas regras de acordo com a PEC n. 287/2016}

O texto original da PEC 287/2016, que foi enviado ao Congresso, já sofreu algumas alterações, estas feitas pelo relator do projeto, Deputado Federal Arthur de Oliveira Maia (PPS - BA). Ressalta-se que, inicialmente, o Governo Temer propôs medidas iguais para homens e mulheres e para trabalhadores urbanos e rurais, contudo, por não conseguir apoio suficiente à aprovação da redação inicial da PEC 287/2016, alguns dos requisitos mínimos exigidos para a concessão de benefícios foram ajustados. Por exemplo, a idade mínima para a obtenção da aposentadoria, que tinha como proposta original fixar em 65 anos, para ambos os sexos e também sem diferenciar os trabalhadores rurais dos urbanos, foi flexibilizada pelo relator da reforma, definindo, como idade mínima, 60 anos para os homens que exercem atividade rural, 57 para as trabalhadoras rurais e 62 anos para trabalhadoras urbanas.

O Quadro 2 demonstra as principais mudanças propostas pelo governo, considerando o relatório aprovado pela Comissão Especial da Reforma da Previdência na Câmara em maio de 2017. 
Quadro 2

Principais mudanças nas regras para a concessão dos benefícios

\begin{tabular}{|c|c|c|}
\hline Benefícios & Regras atuais & Regras após aprovação da PEC 287/2016 \\
\hline $\begin{array}{l}\text { Aposentadoria } \\
\text { Urbana }\end{array}$ & $\begin{array}{l}\text { - Existem duas modalidades principais de aposentadoria no RGPS: } \\
\text { aposentadoria por idade e aposentadoria por tempo de contribuição; } \\
\text { - Na aposentadoria por idade, é exigida a carência de } 15 \text { anos de contribuição } \\
\text { para homens que tenham no mínimo } 65 \text { anos e para mulheres que tenham } 60 \\
\text { anos ou mais; } \\
\text { - Na aposentadoria por tempo de contribuição não há requisito de idade } \\
\text { mínima. O tempo de contribuição é de } 35 \text { anos para homens e } 30 \text { anos para } \\
\text { mulheres; } \\
\text { - A renda mensal da aposentadoria é calculada pela média aritmética simples } \\
\text { dos maiores salários de contribuição correspondente a } 80 \% \text { de todo o período } \\
\text { contributivo, multiplicada pelo fator previdenciário, portanto os } 20 \% \text { menores } \\
\text { são desconsiderados no cálculo; } \\
\text { - A Lei } 13.183 / 2015 \text { introduziu a fórmula } 85 / 95 \text { para o cálculo do valor do } \\
\text { benefício, possibilitando a obtenção da chamada aposentadoria integral (sem } \\
\text { incidência do fator previdenciário). }\end{array}$ & $\begin{array}{l}\text { - Para ter direito a se aposentar, os trabalhadores deverão atingir uma idade } \\
\text { mínima, ou seja, não bastará completar somente o requisito tempo de } \\
\text { contribuição; } \\
\text { - As mulheres deverão atingir no mínimo } 62 \text { anos e os homens } 65 \text { anos. Além } \\
\text { disso, todos deverão contribuir por, no mínimo, } 25 \text { anos, aumentando a } \\
\text { carência em } 10 \text { anos; } \\
\text { - Mudança na regra do cálculo do benefício, que começa com o percentual de } \\
70 \% \text { da média dos salários de contribuição quando o trabalhador completa } 25 \\
\text { anos de contribuição, chegando aos } 100 \% \text { apenas quando completar } 40 \text { anos de } \\
\text { contribuição. Usará a metodologia de cálculo sobre todas as contribuições, sem } \\
\text { a dispensa das menores, como é feito atualmente. }\end{array}$ \\
\hline $\begin{array}{l}\text { Aposentadoria } \\
\text { Rural }\end{array}$ & $\begin{array}{l}\text { - Os trabalhadores rurais, ao solicitarem a aposentadoria por idade, possuem } \\
\text { uma redução de cinco anos no requisito idade, isto é, os homens podem se } \\
\text { aposentar com } 60 \text { anos e as mulheres com } 55 \text { anos. Para isso, precisam } \\
\text { comprovar que exerceram atividade rural por, no mínimo, } 15 \text { anos; } \\
\text { - A contribuição ao regime previdenciário é feita mediante a cobrança de um } \\
\text { percentual incidente sobre a receita da comercialização de sua produção. }\end{array}$ & $\begin{array}{l}\text { - Os trabalhadores rurais da economia familiar poderão se aposentar aos } 57 \\
\text { anos (mulheres) e } 60 \text { anos (homens), com pelo menos } 15 \text { anos de contribuição } \\
\text { para o INSS, ou seja, não basta apenas comprovar o exercício da atividade } \\
\text { rural; } \\
\text { - A contribuição poderá ter valor igual ou inferior ao do MEI } \\
\text { (microempreendedor individual, atualmente } 5 \% \text { do salário mínimo) e será } \\
\text { definida em lei; } \\
\text { - Neste caso, os indivíduos que atuam em regime de economia familiar } \\
\text { deverão fazer contribuição individual e mensal. }\end{array}$ \\
\hline $\begin{array}{l}\text { Aposentadoria } \\
\text { da pessoa com } \\
\text { deficiência }\end{array}$ & $\begin{array}{l}\text { - A Lei Complementar } 142 / 2013 \text { foi aprovada para regulamentar o } \$ 1^{\circ} \text { do art. } \\
201 \text { da Constituição Federal, estabelecendo os seguintes requisitos para a } \\
\text { concessão de aposentadoria pelo RGPS do segurado com deficiência: } \\
\text { - Na aposentadoria por idade, os homens podem se aposentar com } 60 \text { anos e } \\
\text { as mulheres com } 55 \text { anos, desde que cumprido tempo mínimo de } \\
\text { contribuição de } 15 \text { anos e comprovada a existência de deficiência durante } \\
\text { igual período, independentemente do grau de deficiência; } \\
\text { - Na aposentadoria por tempo de contribuição, é exigido tempo de } \\
\text { contribuição variável de acordo com o grau de deficiência e o sexo. }\end{array}$ & $\begin{array}{l}\text { - Não será exigida idade mínima; } \\
\text { - Haverá alterações no tempo de contribuição: } 20 \text { anos para deficiência grave, } \\
25 \text { anos para deficiência moderada e } 35 \text { anos para deficiência leve. Não foram } \\
\text { previstos tempos diferentes em relação ao sexo do segurado. } \\
\text { - O benefício acima do salário mínimo será calculado com base em } 100 \% \text { da } \\
\text { média das contribuições. }\end{array}$ \\
\hline
\end{tabular}


Quadro 2 - Continuação

\begin{tabular}{|c|c|c|}
\hline Benefícios & Regras atuais & Regras após aprovação da PEC 287/2016 \\
\hline $\begin{array}{l}\text { Aposentadoria } \\
\text { especial para } \\
\text { quem exerce } \\
\text { atividades } \\
\text { prejudiciais à } \\
\text { saúde }\end{array}$ & $\begin{array}{l}\text { - Atualmente, para a aposentadoria especial (insalubridade e condições } \\
\text { prejudiciais à integridade física) não há requisito de idade mínima. Exige-se } \\
\text { que o trabalhador tenha tempo de exercício profissional em situações } \\
\text { prejudiciais à saúde, por } 15,20 \text { ou } 25 \text { anos, dependendo do tipo de exposição. } \\
\text { - O valor dessa aposentadoria corresponde à média de } 80 \% \text { dos maiores } \\
\text { salários de contribuição e não se aplicam o fator previdenciário nem a regra } \\
85 / 95 \text {. }\end{array}$ & $\begin{array}{l}\text { - Será exigida uma idade mínima, porém com uma redução de até } 10 \text { anos em } \\
\text { comparação à idade mínima da aposentadoria urbana. No tempo mínimo de } \\
\text { contribuição, a redução será de até } 5 \text { anos para o setor público e } 10 \text { anos para o } \\
\text { setor privado. } \\
\text { - Em relação à aposentadoria especial, a alteração proposta pelo governo } \\
\text { requer o exercício de atividades que efetivamente prejudiquem a saúde. A } \\
\text { periculosidade, isto é, o risco à integridade física deixa de ser critério para } \\
\text { concessão. }\end{array}$ \\
\hline $\begin{array}{l}\text { Aposentadoria } \\
\text { por invalidez }\end{array}$ & $\begin{array}{l}\text { - A legislação protege a invalidez decorrente não somente de acidente de } \\
\text { trabalho, mas também de moléstia profissional ou outras afecções que estão } \\
\text { descritas no art. } 151 \text { da Lei } 8.213 / 91 \text {. Atualmente, todos os casos de invalidez } \\
\text { recebem aposentadoria integral (média dos } 80 \% \text { maiores salários de } \\
\text { contribuição). }\end{array}$ & $\begin{array}{l}\text { - Mudança no formato da aposentadoria por invalidez, através da alteração da } \\
\text { denominação "aposentadoria por invalidez permanente" para "aposentadoria } \\
\text { por incapacidade permanente para o trabalho". } \\
\text { - Esse novo formato tem como pretensão excluir a condição de invalidez que } \\
\text { decorre de moléstia profissional ou de doença grave, contagiosa ou incurável. }\end{array}$ \\
\hline $\begin{array}{l}\text { Pensão por } \\
\text { morte }\end{array}$ & $\begin{array}{l}\text { - Atualmente é permitido o acúmulo de pensão com aposentadoria, bem como } \\
\text { o acúmulo de pensões quando oriundas de regimes distintos; } \\
\text { - A Lei } 13.135 / 2015 \text { trouxe algumas mudanças quanto ao tempo de duração da } \\
\text { pensão, visto que passou a considerar a idade do pensionista no dia do óbito do } \\
\text { segurado. } \\
\text { - A renda mensal da pensão por morte é } 100 \% \text { do valor da aposentadoria que o } \\
\text { segurado recebia ou daquela a que teria direito se estivesse aposentado por } \\
\text { invalidez na data do seu falecimento. }\end{array}$ & $\begin{array}{l}\text { - O valor acima de um salário mínimo será definido por uma cota familiar de } \\
50 \% \text {, acrescida de } 10 \% \text { por dependente, até o limite de } 100 \% \text {; } \\
- \text { O acúmulo de pensão com aposentadoria poderá ocorrer até o limite de dois } \\
\text { salários mínimos. Acima desse limite, opta-se pelo benefício de maior valor; } \\
\text { - Será vedada a acumulação de pensões, mesmo quando provenientes de } \\
\text { regimes diferentes. }\end{array}$ \\
\hline $\begin{array}{l}\text { Benefício } \\
\text { assistencial } \\
\text { para baixa } \\
\text { renda } \\
\text { (BPC/LOAS) }\end{array}$ & $\begin{array}{l}\text { - De acordo com o Decreto 6.214/2007, é um benefício assistencial que } \\
\text { garante um salário mínimo mensal à pessoa com deficiência e ao idoso, com } \\
\text { idade de } 65 \text { anos ou mais, que comprovem não possuir meios para prover a } \\
\text { própria manutenção, nem tê-la provida por sua família; } \\
\text { - Para fazer jus ao benefício, deve-se comprovar uma renda bruta mensal } \\
\text { familiar per capita inferior a um quarto do salário mínimo. }\end{array}$ & $\begin{array}{l}\text { - Será concedido para idosos com idade mínima de } 68 \text { anos e pessoas com } \\
\text { deficiência, de qualquer idade. } \\
\text { - Impõe a limitação no acesso aos benefícios assistenciais em razão do cálculo } \\
\text { do valor da renda per capita mensal familiar que passará a considerar a } \\
\text { integralidade de todas as fontes renda da família. }\end{array}$ \\
\hline
\end{tabular}

Fontes: Anfip e Dieese (2017); Ministério da Fazenda (Brasil, 2017b); Secretaria da Previdência (Brasil, 2017e); Lei 13.183/2015 (Brasil, 2015a); Lei 13.135/2015 (Brasil, 2015b);

Lei Complementar 142/2013 (Brasil, 2013); Decreto 6.214/2007 (Brasil, 2007); Lei 8.213/1991 (Brasil, 1991). 
Destaca-se que praticamente todas as alterações que estão sendo propostas no RGPS aplicar-se-ão também para as aposentadorias dos servidores públicos federais civis. Também sofrerão mudanças as aposentadorias dos professores e dos policiais federais, rodoviários federais, ferroviários federais, legislativos e policiais civis. Para o Governo, as novas regras trarão mais igualdade e acabarão com as vantagens de determinadas categorias (Brasil, 2017a).

Para Wagner, Rambo e Andrade:

A reforma proposta agora só pretende repetir o que tem ocorrido nas sucessivas reformas da Previdência que foram feitas desde 1998. O foco é, sempre, em mudar os benefícios para reduzir seu valor e aumentar os requisitos e carências. Em consequência, os prejudicados são sempre aqueles que trabalham e que precisarão fazer uso do sistema. Entretanto, não se busca atacar as causas reais dos problemas que se alega existir na Previdência Social, o que poderia ser feito extinguindo a permissão de usar os recursos das contribuições sociais para outros fins, reduzindo as renúncias fiscais, cobrando as dívidas e combatendo a corrupção que surrupia estes recursos (Wagner; Rambo; Andrade, 2017, p. 8).

Em relação aos interesses subjacentes à reforma previdenciária, esta possui dois objetivos, os quais estão diretamente conectados aos ganhos do setor financeiro. O primeiro é o de adequar as despesas da Seguridade às regras impostas pela Emenda Constitucional 95/2016, que restringiu o crescimento das despesas primárias da União, considerando como teto o valor referente ao exercício imediatamente anterior, corrigido apenas pela variação do Índice Nacional de Preços ao Consumidor Amplo - IPCA. Esse "Novo Regime Fiscal" foi aprovado para os próximos 20 anos com o propósito de utilizar recursos, inclusive da Seguridade, para o pagamento de juros e serviços da dívida pública (Chinaglia et al., 2017).

Logo, para conseguir cumprir com a EC 95/2016, o Governo Temer precisa aprovar a PEC 287/2016, pois assim diminuirá as despesas por meio da redução do valor das aposentadorias e pensões, bem como do número de benefícios concedidos devido à criação de regras mais rígidas.

O segundo objetivo é estimular o desenvolvimento do mercado financeiro a partir dos planos privados de previdência. É inevitável que o estabelecimento de obstáculos para o acesso à previdência pública desestimule a contribuição a este regime, de tal forma que, quem possui mais recursos buscará alternativas oferecidas pelas instituições financeiras (Chinaglia et al., 2017). Anfip e Dieese (2017, p. 99) dizem que: “[...] a privatização parece ser propósito não manifesto da reforma".

Anfip e Dieese (2017) salientam alguns dos retrocessos que esta reforma trará para a sociedade. O primeiro é a elevação da carência do tempo de contribuição de 15 para 25 anos, sem considerar o histórico de alta rotatividade no emprego e a elevada informalidade existente no Brasil. Outra preocupação é que, além da fixação da idade mínima para todas as categorias de aposentadoria, a PEC 287/2016 prevê o aumento automático das idades 
mínimas para a percepção dos benefícios cada vez que crescer a expectativa média de sobrevida dos brasileiros. Sobre o assunto, Wagner, Rambo e Andrade (2017) dizem que este dispositivo pode causar um sério problema, uma vez que o cálculo da expectativa de sobrevida é feito pela média nacional e, por isso, é imprescindível que se considerem as diferenças que existem entre as regiões do Brasil.

A situação dos segurados especiais (trabalhadores rurais) também será afetada consideravelmente, dado que, desde a Constituição Federal de 1988, a contribuição para o sistema previdenciário é feita mediante uma alíquota da receita da comercialização da produção. De acordo com as novas regras, a contribuição passará a ser mensal e individual, tornando-se incompatível com a sazonalidade e as características da produção rural, desconsiderando que muitas famílias não auferem renda suficiente para pagar os valores que serão exigidos (Anfip; Dieese, 2017).

Fagnani (2017) alerta para o fato de que o Brasil (por meio das medidas econômicas propostas pelo Governo Temer) está caminhando na mesma direção que o México, ao considerar que, na década de 1990, este país instituiu algumas medidas neoliberais que acabaram trazendo várias consequências, tais como: a alta informalidade do mercado de trabalho, a não contribuição da maioria dos trabalhadores economicamente ativos para o sistema previdenciário, o elevado número de idosos desprotegidos e um percentual considerável da população que se encontra em situação de pobreza.

Após a análise das possíveis implicações da reforma previdenciária brasileira, tornase pertinente saber se é viável recorrer a alternativas diferentes. Destarte, na próxima subseção serão indicadas algumas das possibilidades que podem garantir o equilíbrio financeiro da Previdência e da Seguridade e, ao mesmo tempo, evitar que direitos sociais sejam subtraídos.

\subsection{As alternativas para garantir a sustentabilidade da Previdência}

Considerando os resultados apresentados sob a perspectiva constitucionalista, não há déficit na Previdência e um dos mecanismos para que se mantenha o equilíbrio financeiro desse sistema protetivo é reivindicar que as receitas citadas nos artigos 194 e 195 da Constituição Federal de 1988 sejam aplicadas na Seguridade Social, ou seja, os recursos oriundos da arrecadação da Cofins, CSLL e PIS/Pasep devem ter a correta destinação, respeitando o princípio da diversidade da base de financiamento.

Além das já mencionadas desonerações e renúncias previdenciárias, que devem ser revistas, Anfip e Dieese (2017) sugerem o aumento da contribuição do setor do agronegócio, visto que, em 2016, os resultados deste setor representaram $23 \%$ do PIB, enquanto que a sua participação foi de apenas $0,5 \%$ do total arrecadado para a Previdência. Há também observações quanto a criar incentivos para a inserção dos trabalhadores informais, pois estariam protegidos pelo sistema, passando a contribuir para o mesmo. 
Outra sugestão é o reforço da fiscalização e um aperfeiçoamento na gestão administrativa e financeira da Previdência, pois estas ações elevariam significativamente a arrecadação. Entre 2011 a 2015, o montante da dívida ativa previdenciária disparou, mudando de $\mathrm{R}$ \$ 185,8 bilhões para $\mathrm{R} \$ 350,7$ bilhões, sem considerar o valor não contabilizado em razão da sonegação, comprovando, então, a necessidade de intensificar a fiscalização. Anfip e Dieese dizem que:

Diante desses fatos, é perfeitamente compreensível que o cidadão comum se pergunte por que deveria aceitar uma reforma da Previdência que procura achatar sua renda, quando o próprio governo não se mostra nem desejoso e nem capaz de gerir com competência a cobrança de tributos das empresas devedoras (Anfip; Dieese, 2017, p. 177).

De forma a complementar as observações acima sobre a postura do Estado, a CPIPrev (2017) indica seis atitudes que impactam negativamente no resultado financeiro da previdência e que poderiam ser reexaminadas: 1) a participação contributiva para a previdência que, até o momento, não respeita o financiamento tripartite (trabalhadores, empresas e Estados), uma vez que, por parte do Estado, o aporte de recursos sempre foi reduzido e incerto; 2) a utilização de recursos previdenciários para políticas de industrialização, capitalização de empresas estatais e para a realização de grandes obras, sem o respectivo retorno financeiro; 3) a destinação de recursos da seguridade social para outros gastos com interesses adversos a partir do mecanismo da DRU; 4) o descumprimento de dispositivo constitucional em favor de empresas, já que está previsto no art. $195 \S 3^{\circ}$ da Constituição Federal de 1988 que a pessoa jurídica em débito com a seguridade social não poderá contratar com o Poder Público, nem receber incentivos fiscais ou creditícios por parte do governo; 5) permitir que as próprias empresas estatais sejam grandes devedoras da previdência social, tais como o Banco do Brasil e Caixa Econômica Federal; 6) não haver ou ser insuficiente a compensação das renúncias fiscais no âmbito das receitas previdenciárias.

Ressalta-se também que as regras de decadência e prescrição das contribuições previdenciárias devem ser reavaliadas a fim de mitigar as sonegações. As normas devem ser compatíveis com o Direito Previdenciário, já que muitos contribuintes não recolhem as contribuições devidas (suas e de seus empregados) por terem conhecimento de que a Fazenda Pública tem um curto prazo para constituir o lançamento do crédito tributário e para promover a ação de cobrança do crédito lançado. É grande o impacto gerado pela sonegação, pois os segurados têm o direito de receber os benefícios, mesmo que seus empregadores não tenham feito o recolhimento das contribuições que são descontadas de seus salários. Por esta razão, Anfip e Dieese (2017, p. 180) questionam: "até que ponto a Previdência Social conseguirá pagar benefícios contando com contribuições de 15 a 35 anos de contribuição, se não pode cobrar as contribuições decorrentes da sonegação ou de decisões judiciais, principalmente na Justiça do Trabalho, após cinco anos? “.

Em relação ao cenário macroeconômico, não se pode desconsiderar que vem aumentando o número de pessoas desocupadas no Brasil e, consequentemente, o número de 
pessoas que deixam de contribuir para a Previdência. Os dados do IBGE (2017) demonstram que a taxa de desocupação do primeiro trimestre de 2017 foi estimada em 13,7\%, o que representa um aumento de 1,7\% em comparação com o quarto trimestre de 2016. Portanto, a retomada do crescimento econômico é determinante para o equilíbrio da Previdência, necessariamente, porque a arrecadação provém tanto dos segurados quanto das contribuições dos empregadores, incidentes sobre a folha de salário, o faturamento e o lucro das empresas.

De todas essas possibilidades descritas, uma das principais medidas citadas por diversos estudiosos é a imprescindível reforma tributária. De acordo com Fagnani (2017), para que se tenha a sustentabilidade da Previdência, a incidência de impostos deve prevalecer sobre a riqueza e a renda, que só aumentam, e não sobre a base salarial, que só diminui. Anfip e Dieese (2017, p. 187) complementam ao dizer que uma "[...] reforma tributária corretamente pensada e executada pode, simultaneamente, fazer justiça fiscal e justiça social: ampliar a arrecadação, retomar o crescimento, preservar o Estado Social e reduzir as desigualdades".

Portanto, há alternativas que vão desde mudanças estruturais do setor, ou seja, diretamente relacionadas com a Previdência e a Seguridade Social, até mecanismos mais externos, isto é, políticas macroeconômicas que gerariam crescimento da economia e, como resultado, aumento da arrecadação.

Após explanar as alternativas que resolveriam o "problema financeiro", deve-se avaliar se o crescente envelhecimento da população pode impactar na sustentabilidade do sistema previdenciário brasileiro. Sabe-se que a Previdência Social, assim como outras políticas públicas, deve ser revista e adaptada à realidade social do país, de forma a respeitar os critérios que preservem o equilíbrio financeiro e atuarial, conforme consta no artigo 201 da Constituição Federal vigente.

O principal argumento utilizado pelo Governo para aprovar a PEC 287/2016 é que haverá um forte crescimento das despesas previdenciárias e assistenciais em razão do acelerado processo de envelhecimento da população. Os dados divulgados pelo poder público fazem um comparativo entre o número aproximado de idosos que temos atualmente no Brasil - cerca de onze para cada cem pessoas em idade ativa - com a projeção do número de idosos para 2060 - quarenta e quatro idosos - (Brasil, 2017a). Quanto às projeções apresentadas pelo governo para o ano de 2060, existem muitas críticas, inclusive, relatadas pela CPIPrev (2017), indicando graves falhas no modelo atuarial, as quais são apontadas tanto pelo TCU, quanto pelos especialistas que participaram das audiências da Comissão Parlamentar de Inquérito da Previdência.

Giambiagi, Oliveira e Beltrão (1996) já defendiam a necessidade de reformas na Previdência ao afirmarem que os problemas são o envelhecimento demográfico da população e as brandas regras de aposentadoria que acabam agravando a situação financeira desse sistema. Diante disso, percebe-se que faz, no mínimo, vinte anos que os apoiadores das reformas utilizam o mesmo discurso para embasar as reformas ocorridas desde então. 
Embora existam controvérsias em relação às projeções, não há como negar este crescente envelhecimento da população brasileira, resultante da combinação da elevação da esperança de vida ao nascer com a redução na taxa de fecundidade. Tal situação pode ser compreendida como uma ameaça ao equilíbrio das contas da previdência pública no longo prazo.

A partir das projeções demográficas de 2008 do IBGE, Giambiagi e Tafner (2011) elaboraram dois gráficos, conforme Figura 1, que demonstram o aumento significativo do número de idosos no total da população e, ao mesmo tempo, um encolhimento da participação de segmentos mais jovens quando comparado o ano de 2000 em relação à projeção para 2040. Para os autores, "como reflexo desse processo de envelhecimento, a pirâmide etária perde progressivamente o formato triangular (típica de países jovens) para assumir um formato trapezional" (Giambiagi; Tafner, 2011, p. 92).

Figura 1

Pirâmides etárias brasileiras de 2000 e 2040

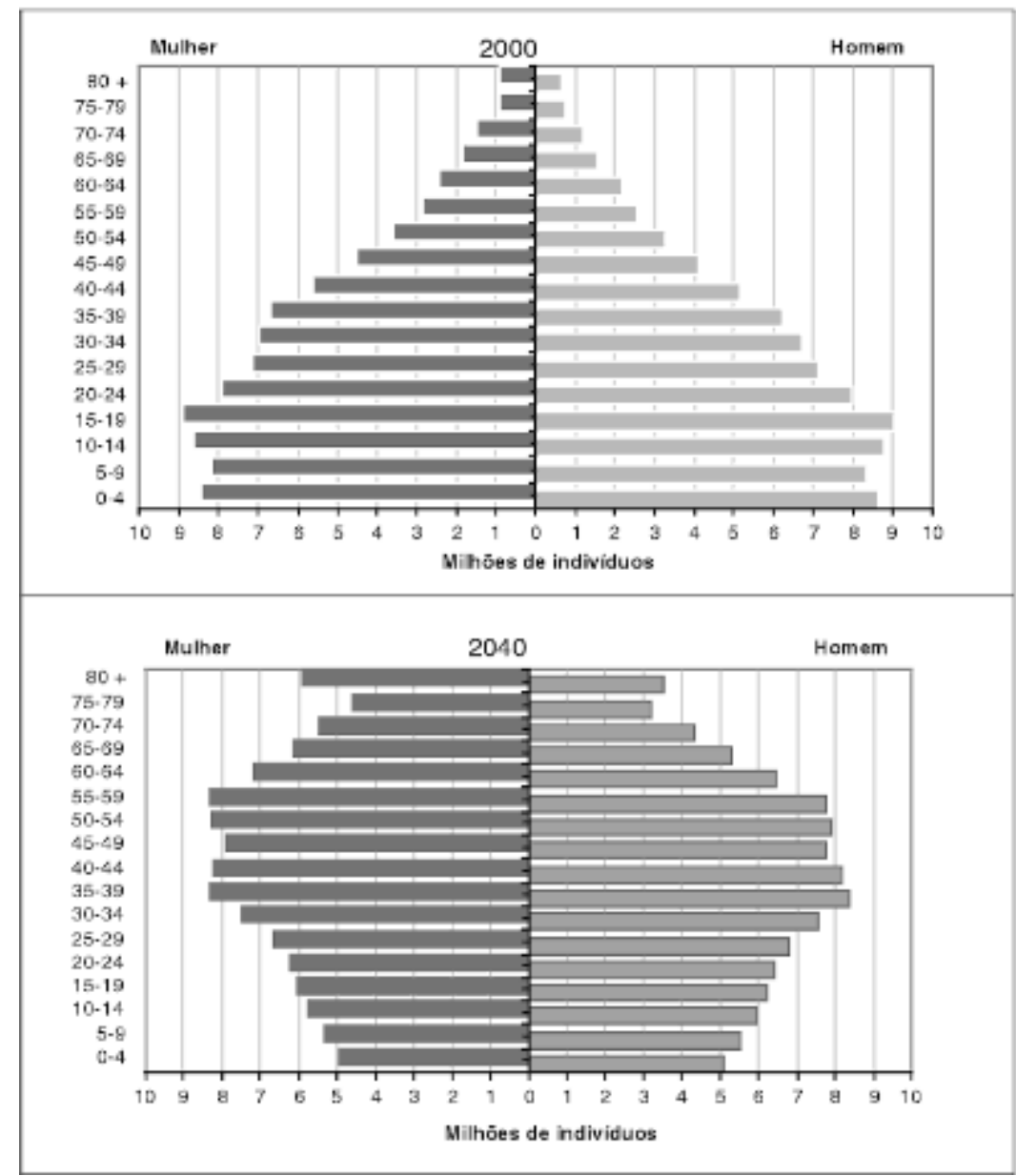

Fonte: Giambiagi e Tafner (2011, p. 93). 
Algumas mudanças no sistema previdenciário já estão ocorrendo, porém de forma pontual. Em 2015, foi sancionada a Lei 13.135, a qual prevê novas normas para a percepção dos benefícios auxílio-doença e pensão por morte, na tentativa de inibir fraudes e, principalmente, no caso da pensão, de adequar o tempo de benefício concedido à estimativa de sobrevida do dependente (cônjuge ou companheiro), deixando de ser, como regra, uma pensão vitalícia. Também, no ano de 2015, foi aprovada a Lei 13.183, que trata, entre outros aspectos, da não incidência do fator previdenciário no cálculo da aposentadoria por tempo de contribuição, tendo como objetivo a redução do número de aposentadorias precoces.

Todavia, as modificações demográficas que estão ocorrendo no Brasil representam um desafio muito maior para a continuidade do sistema previdenciário no país. Giambiagi e Tafner (2011) dizem que:

[...] Quanto mais as pessoas viverem - o que é excelente para os indivíduos e uma conquista da sociedade brasileira -, mantidas as condições e regras atuais, mais esse fenômeno poderá implicar aumento do passivo previdenciário, demandando maiores parcelas do produto, limitando a capacidade de poupança e de investimento, e impondo um ônus elevado para as gerações futuras (Giambiagi; Tafner, 2011, p. 95).

Desta forma, não se exclui que, no decorrer de alguns anos, deva ocorrer um ajuste no sistema previdenciário a fim de adequar as regras de concessão de benefícios à expectativa de sobrevida dos brasileiros. Embora o Governo Temer tenha proposto uma idade mínima para obtenção da aposentadoria, a PEC 287/2016 não se mostra apropriada porque não observa as desigualdades de renda e riqueza, do mercado de trabalho, da expectativa de sobrevida e da expectativa de duração dos próprios benefícios, ignorando que o Brasil é um país heterogêneo sob o aspecto social, econômico, demográfico e regional (Anfip; Dieese, 2017).

\section{Considerações finais}

Constata-se a importância da Previdência Social, visto ser um sistema de proteção que ampara milhões de brasileiros e que tem como objetivo principal garantir um padrão de vida considerado satisfatório. Entretanto, a essência deste sistema está sendo desconstruída sucessivamente, desde a promulgação da Constituição Federal de 1988. Todas as reformas previdenciárias que vêm sendo realizadas não geraram segurança para a população quanto à solução do "problema financeiro", alegado pelos governantes, principalmente, porque sucessivamente utilizam justificativas parecidas, o que faz pensar que com aprovação da PEC 287/2016 não será diferente, não tendo como prever uma estabilidade na política previdenciária.

Além disso, diante da atual recessão econômica, tem se debatido que a necessidade de se aprovar esta reforma se dá, principalmente, em razão do sistema ser deficitário, isto é, apresentar um histórico de arrecadação menor do que o valor gasto com os pagamentos dos benefícios. Todavia, o déficit, utilizado como a principal justificativa para tal reforma, é 
questionável sob vários aspectos constitucionais, bem como historicamente, já que o relatório da CPIPrev (2017) aponta que, até a década de 1980, a Previdência apresentou superávits e que, desde 1990, parte dos recursos que deveriam ser destinados à Seguridade Social foram desviados em razão da DRU. Portanto, é imponderado falar em déficit crescente, quando recursos previdenciários são apropriados pelo Governo Federal para diversas finalidades, não havendo a preocupação de se fazer uma reserva para cobertura de eventuais desequilíbrios, tampouco a reposição desses valores desviados.

Logo, embora o Governo Temer alegue que este saldo negativo vem agravando a situação das contas públicas, entende-se que a Previdência Social não é um agravante da atual crise econômica, mas refém dela.

Em relação à coerência das informações que são divulgadas, questiona-se se este é o momento adequado para se fazer cortes na área de maior proteção social do país, principalmente, porque vem aumentando o número de pessoas desocupadas. Para o atual governo, ao reduzir despesas, será possível equilibrar as contas públicas e, assim, incentivar o crescimento econômico e a geração de empregos. Todavia, os opositores à reforma afirmam que realizar cortes nos gastos sociais não garantirá o equilíbrio da Previdência, pois a arrecadação previdenciária é um reflexo de fatores externos, ligados à política econômica e ao mercado de trabalho.

Levando em consideração o crescente envelhecimento da população brasileira, poderá haver a necessidade de se fazer ajustes nas regras de concessão de benefícios visando à sustentabilidade do sistema no longo prazo. Contudo, entende-se que é frágil a justificativa de reformar o sistema para garantir a sua sobrevivência, nos termos da PEC 287/2016, por representar uma modificação muito abrangente, que tende a afetar todo o sistema da Seguridade Social, desprezando as desigualdades existentes no Brasil. Chega-se à conclusão de que cortar gastos públicos, através da redução de direitos, neste momento, não é a única nem a melhor alternativa para manter esse sistema saudável, fato este que permite a interpretação da existência de objetivos, por parte do Governo, que não são expostos para a sociedade.

Ademais, não se pode deixar de observar que, contrariando o discurso da imprescindibilidade da aprovação da PEC 287/2016 para a sobrevivência do referido sistema, o governo encaminhou ao Congresso Nacional outras medidas (reforma trabalhista, lei da terceirização, teto dos gastos e o aumento das desvinculações de receitas) que afetam substancialmente a própria Previdência, ressaltando a incoerência do "objetivo" da reforma garantir a perpetuidade do sistema previdenciário.

Por fim, para dar continuidade a este estudo, sugere-se analisar, principalmente, as alterações aprovadas na legislação trabalhista, oriundas das leis 13.467/2017 e 13.429/2017, que possam trazer implicações para o sistema previdenciário, a fim de explorar possíveis consequências para o mercado de trabalho no Brasil, bem como trazer subsídios que auxiliem na compreensão do novo modelo de Estado que tende a se consolidar a partir dessas reformas. 


\section{Referências bibliográficas}

ASSOCIAÇÃO NACIONAL DOS AUDITORES FISCAIS DA RECEITA FEDERAL DO BRASIL - Anfip. Análise da Seguridade Social 2016. Brasília: Anfip, 2017. 192p. Disponível em: https://www.anfip.org.br/doc/publicacoes/Livros_24_10_2017_11_48_10.pdf. Acesso em: 20 mar. 2018.

ASSOCIAÇÃO NACIONAL DOS AUDITORES FISCAIS DA RECEITA FEDERAL DO BRASIL - Anfip. Análise da Seguridade Social 2015. 16. ed. Brasília: Anfip, 2016. 150p. Disponível em: https://www.anfip.org.br/doc/publicacoes/20161013104353 Analise-daSeguridade-Social-2015_13-10-2016_Anlise-Seguridade-2015.pdf. Acesso em: 16 jun. 2017.

ASSOCIAÇÃO NACIONAL DOS AUDITORES FISCAIS DA RECEITA FEDERAL DO BRASIL - ANFIP / DEPARTAMENTO INTERSINDICAL DE ESTATÍSTICA E ESTUDOS SOCIOECONÔMICOS - Dieese. Previdência: reforma para excluir? Brasília: Anfip/Dieese, 2017. 212p. Contribuição técnica ao debate sobre a reforma da previdência social brasileira. Disponível em: < http://fundacaoanfip.org.br/site/wpcontent/uploads/2017/02/Previd\%C3\%AAncia-Reformar-para-excluir-Documento-

Completo.pdf. Acesso em: 24 maio 2017.

BRASIL. MINISTÉRIO DA PREVIDÊNCIA SOCIAL. Para entender a Reforma da Previdência. Brasília: Ministério da Previdência Social, 2017a. Disponível em: http://reformadaprevidencia.gov.br/upload/previdencia/entenda/cartilha-previdencia-1-.pdf. Acesso em: 5 ago. 2017.

BRASIL. MINISTÉRIO DA FAZENDA. Por dentro da Reforma da Previdência. 2017b. Disponível em: http://www.fazenda.gov.br/por-dentro-da-reforma-da-previdencia. Acesso em: 22 jun. 2017.

BRASIL. MINISTÉRIO DA FAZENDA. Dívida Pública Federal: Relatório Anual 2016. 14. ed. Brasília: Secretaria do Tesouro Nacional, 2017c. Disponível em: http://www.tesouro.fazenda.gov.br/documents/10180/269444/RAD_2016_ptbr.pdf/ec1dfc42-8088-49ad-9bb7-535a220307e6. Acesso em: 23 maio 2017.

BRASIL. TESOURO NACIONAL. Relatório resumido da execução orçamentária do Governo Federal e outros demonstrativos. Brasília: Ministério da Fazenda, 2017d. 48p. Disponível em: http://www.tesouro.fazenda.gov.br/documents/10180/352657/RREOjan2017. pdf/7a4f1571-90b2-4b60-afed-2fff28f6f2ac. Acesso em: 21 jun. 2017.

BRASIL. SECRETARIA DE PREVIDÊNCIA. Resultado do Regime Geral de Previdência Social 2016. Brasília: Ministério da Fazenda, 2017e. Disponível em: http://www.fazenda.gov.br/centrais-de-conteudos/apresentacoes/2017/resultado-do-regimegeral-de-previdencia-social-rgps.pdf. Acesso em: 15 jun. 2017.

BRASIL. CONSTITUIÇÃO (1988). Constituição da República Federativa do Brasil: texto constitucional promulgado em 5 de outubro de 1988, com as alterações determinadas pelas 
Emendas Constitucionais de Revisão nos 1 a 6/94, pelas Emendas Constitucionais nos 1/92 a 91/2016 e pelo Decreto Legislativo no 186/2008. Brasília, DF: Senado Federal, Coordenação de Edições Técnicas, 2016. Disponível em: https://www2.senado.leg.br/bdsf/bitstream/handle/id/518231/CF88_Livro_EC91_2016.pdf?s equence $=1$. Acesso em: 01 jun. 2017.

BRASIL. Lei $n$. 13.183, de 04 de novembro de 2015. Altera as Leis n. 8.212, de 24 de julho de 1991, e 8.213, de 24 de julho de 1991, para tratar da associação do segurado especial em cooperativa de crédito rural e, ainda essa última, para atualizar o rol de dependentes, estabelecer regra de não incidência do fator previdenciário, regras de pensão por morte e de empréstimo consignado, a Lei n. 10.779, de 25 de novembro de 2003, para assegurar pagamento do seguro-defeso para familiar que exerça atividade de apoio à pesca, a Lei n. 12.618, de 30 de abril de 2012, para estabelecer regra de inscrição no regime de previdência complementar dos servidores públicos federais titulares de cargo efetivo, a Lei n. 10.820, de 17 de dezembro de 2003, para dispor sobre o pagamento de empréstimos realizados por participantes e assistidos com entidades fechadas e abertas de previdência complementar e a Lei n. 7.998, de 11 de janeiro de 1990; e dá outras providências. Brasília, DF, 2015a. Disponível em: http://www.planalto.gov.br/ccivil_03/_ato20152018/2015/lei/113183.htm. Acesso em: 5 ago. 2017.

BRASIL. Lei $n$. 13.135, de 17 de junho de 2015. Altera as Leis n. 8.213, de 24 de julho de 1991, n. 10.876, de 2 de junho de 2004, n. 8.112, de 11 de dezembro de 1990, e n. 10.666, de 8 de maio de 2003, e dá outras providências. Brasília, DF, 2015b. Disponível em: http://www.planalto.gov.br/ccivil_03/_ato2015-2018/2015/lei/113135.htm. Acesso em: 5 ago. 2017.

BRASIL. Lei Complementar n. 142, de 08 de maio de 2013. Regulamenta o § 1o do art. 201 da Constituição Federal, no tocante à aposentadoria da pessoa com deficiência segurada do Regime Geral de Previdência Social - RGPS. Brasília, DF. Disponível em: http://www.planalto.gov.br/ccivil_03/leis/LCP/Lcp142.htm. Acesso em: 5 ago. 2017.

BRASIL. Decreto n. 6.214, de 26 de setembro de 2007. Regulamenta o Benefício de Prestação Continuada da Assistência Social devido à pessoa com deficiência e ao idoso de que trata a Lei n. 8.742, de 7 de dezembro de 1993, e a Lei n. 10.741, de $1^{\circ}$ de outubro de 2003, acresce parágrafo ao art. 162 do Decreto n. 3.048, de 6 de maio de 1999, e dá outras providências. Brasília, DF. Disponível em: http://www.planalto.gov.br/ccivil_03/_ato20072010/2007/decreto/d6214.htm. Acesso em: 5 ago. 2017.

BRASIL. Lei n. 8213, de 24 de julho de 1991. Dispõe sobre os Planos de Benefícios da Previdência Social e dá outras providências. Brasília, DF. Disponível em: http://www.planalto.gov.br/ccivil_03/leis/L8213cons.htm. Acesso em: 5 ago. 2017.

CHINAGLIA, Arlindo et al. Comissão Especial destinada a proferir parecer à Proposta de Emenda à Constituição n. 287-A, de 2016, do Poder Executivo, que "altera os arts. 37, 40, 
42, 149, 167, 195, 201 e 203 da Constituição, para dispor sobre a Seguridade Social, estabelece regras de transição e dá outras providências: Voto em separado. Bancada do Partido dos Trabalhadores. Brasília: DF, 2017. 58p. Disponível em: http://www2.camara.leg.br/atividade-legislativa/comissoes/comissoestemporarias/especiais/55a-legislatura/pec-287-16-reforma-daprevidencia/documentos/outros-documentos/voto-em-separado-bancada-do-pt. Acesso em: 5 ago. 2017.

COMISSÃO PARLAMENTAR DE INQUÉRITO DO SENADO FEDERAL DESTINADA A INVESTIGAR A CONTABILIDADE DA PREVIDÊNCIA SOCIAL - CPIPrev (Brasil). Senado Federal. Comissão Parlamentar de Inquérito do Senado Federal destinada a investigar a contabilidade da previdência social, esclarecendo com precisão as receitas $e$ despesas do sistema, bem como todos os desvios de recursos (CPIPrev): Relatório Final. Brasília: Senado Federal, 2017. Disponível em: http://legis.senado.leg.br/comissoes/ comissao?0\&codcol=2093. Acesso em: 31 out. 2017.

DEPARTAMENTO INTERSINDICAL DE ESTATÍSTICA E ESTUDOS SOCIOECONÔMICOS - Dieese. Previdência Social brasileira: concepção constitucional e tentativas de desconstrução. São Paulo: Dieese, set. 2007a. 10p. (Nota técnica, n. 51). Disponível em: http://www.dieese.org.br/notatecnica/2007/notatec51Previdencia.pdf. Acesso em: 5 jun. 2017.

DEPARTAMENTO INTERSINDICAL DE ESTATÍSTICA E ESTUDOS SOCIOECONÔMICOS - Dieese. A Previdência Social brasileira tem déficit? São Paulo: Dieese, out. 2007b. 12p. (Nota técnica, n. 52). Disponível em: https://www.dieese.org.br/notatecnica/2007/notate52PrevidenciaDeficit.pdf. Acesso em: 6 jun. 2017.

FAGNANI, Eduardo. Reforma da Previdência: especialista fala tudo o que você precisa saber sobre ela (e o que a mídia não te conta). 2017. Voyager. Disponível em: https://voyager1.net/entrevista/especialista-responde-as-principais-duvidas-sobre-a-reformada-previdencia/. Acesso em: 6 ago. 2017.

FÓRUM 21 et al. Austeridade e retrocesso: finanças públicas e política fiscal no Brasil. São Paulo: Fórum 21; Fundação Friedrich Ebert Stiftung (FES); GT de Macro da Sociedade Brasileira de Economia Política (SEP); e Plataforma Política Social, 2016. 1v. Disponível em: http://brasildebate.com.br/wp-content/uploads/Austeridade-e-Retrocesso.pdf. Acesso em: 20 jul. 2017.

GENTIL, Denise Lobato. a política fiscal e a falsa crise da seguridade social brasileira: análise financeira do período 1990-2005. 2006. 244f. Tese (Doutorado)-Curso de Economia, Instituto de Economia - Centro de Ciências Jurídicas e Econômicas, Universidade Federal do Rio de Janeiro, Rio de Janeiro, 2006. Disponível em: http://www.ie.ufrj.br/images/pesquisa/ 
publicacoes/teses/2006/a_politica_fiscal_e_a_falsa_crise_da_seguraridade_social_brasileira_ analise_financeira_do_periodo_1990_2005.pdf. Acesso em: 06 jun. 2017.

GIAMBIAGI, Fabio; OLIVEIRA, Francisco Eduardo Barreto de; BELTRÃO, Kaizo Iwakami. Alternativas da Reforma da Previdência Social: uma proposta. Revista do $B N D E S$, Rio de Jeneiro, v. 3, n. 6, p. 63-78, dez. 1996. Disponível em: https://web.bndes.gov.br/bib/jspui/handle/1408/11236. Acesso em: 29 maio 2017.

GIAMBIAGI, Fabio; TAFNER, Paulo. Demografia: a ameaça invisível: o dilema previdenciário que o Brasil se recusa a encarar. Rio de Janeiro: Elsevier, 2011.

GOES, Hugo Medeiros. Manual de Direito Previdenciário: teoria e questões. 10. ed. Rio de Janeiro: Ferreira, 2015. 864p.

INSTITUTO BRASILEIRO DE GEOGRAFIA E ESTATÍSTICA - IBGE. Indicadores IBGE: Contas Nacionais Trimestrais. Rio de Janeiro: IBGE, 7 mar. 2017. Trimestral. Indicadores de volume e valores correntes $/ 4^{\circ}$ trimestre de 2016. Disponível em: ftp://ftp.ibge.gov.br/Contas_Nacionais/Contas_Nacionais_Trimestrais/Fasciculo_Indicadores _IBGE/pib-vol-val_201604caderno.pdf. Acesso em: 23 maio 2017.

INSTITUTO BRASILEIRO DE GEOGRAFIA E ESTATÍSTICA - IBGE. Indicadores IBGE: Pesquisa Nacional por Amostra de Domicílio Contínua. Rio de Janeiro: IBGE, 18 maio 2017. Trimestral. Primeiro trimestre de 2017. Disponível em: ftp://ftp.ibge.gov.br/Trabalho e Rendimento/Pesquisa Nacional por Amostra de Domicili os continua/Trimestral/Fasciculos Indicadores IBGE/pnadc 201701 trimestre caderno.pdf. Acesso em: 24 maio 2017.

INSTITUTO NACIONAL DO SEGURO SOCIAL - INSS. Notas Explicativas: Fundo do Regime Geral de Previdência Social (FRGPS). Brasília: Ministério da Fazenda, 2016. Disponível em: http://www.previdencia.gov.br/wp-content/uploads/2017/01/NotasExplicativas_FRGPS_2016_Versão-Final.pdf. Acesso em: 15 jun. 2017.

LÚCIO, Clemente Ganz. Transformações no mercado de trabalho e desafios para a Previdência Social no Brasil. Texto técnico. Brasília: Dieese, 21 mar. 2017. Disponível em: http://www.mps.gov.br/arquivos/office/4_081010-120045-270.pdf. Acesso em: 5 jun. 2017.

SECRETARIA DA RECEITA FEDERAL DO BRASIL. Análise da Arrecadação das Receitas Federais: Dez. 2016. Brasília: Ministério da Fazenda, 2016. Centro de Estudos Tributários e Aduaneiros. Disponível em: https://idg.receita.fazenda.gov.br/dados/receitadata/ arrecadacao/relatorios-do-resultado-da-arrecadacao/arrecadacao-2016/dezembro2016/analisemensal-dez-2016.pdf. Acesso em: 15 jun. 2017.

SECRETARIA DA RECEITA FEDERAL DO BRASIL. Análise da Arrecadação das Receitas Federais: Dez. 2015. Brasília: Ministério da Fazenda, 2015. Centro de Estudos Tributários e Aduaneiros. Disponível em: https://idg.receita.fazenda.gov.br/dados/receitadata/ 
arrecadacao/relatorios-do-resultado-da-arrecadacao/arrecadacao-2015/dezembro2015/analisemensal-dez-2015.pdf. Acesso em: 15 jun. 2017.

SEVERINO, Antonio Joaquim. Metodologia do trabalho científico. 2. ed. São Paulo: Cortez, 2017.

SILVA, Maria Lucia Lopes da. (Des)estruturação do trabalho e condições para a universalização da Previdência Social no Brasil. 2011. 359f. Tese (Doutorado)-Curso de Política Social, Departamento de Serviço Social da Universidade de Brasília, Universidade de Brasília, Brasília, 2011. Disponível em: http://repositorio.unb.br/bitstream/10482/8716/1/ 2011_MariaLuciaLopesDaSilva.pdf. Acesso em: 1 jun. 2017.

WAGNER, José Luis; RAMBO, Luciana Inês; ANDRADE, Valmir Floriano Vieira de. Cartilha crítica da Reforma da Previdência. Brasília: Wagner Advogados Associados, 2017. Disponível em: https://www.anfip.org.br/doc/publicacoes/Documentos $2003 \quad 2017 \quad 18 \quad 29$ _12.pdf. Acesso em: 5 ago. 2017. 